\title{
A Methodical Approach to Design and Valuation of Weather Derivatives in Agriculture
}

\author{
Jindrich Spicka and Jiri Hnilica \\ Department of Business Economics, University of Economics, Prague, W. Churchill Square 4, 13067 Prague 3, Czech Republic \\ Correspondence should be addressed to Jindrich Spicka; jindrich.spicka@vse.cz
}

Received 5 December 2012; Revised 17 April 2013; Accepted 27 May 2013

Academic Editor: Ismail Gultepe

Copyright ( 2013 J. Spicka and J. Hnilica. This is an open access article distributed under the Creative Commons Attribution License, which permits unrestricted use, distribution, and reproduction in any medium, provided the original work is properly cited.

\begin{abstract}
The paper deals with weather derivatives as the potentially effective risk management tool for agricultural enterprises seeking to mitigate their income exposure to variations in weather conditions. Design and valuation of the weather derivatives is an interdisciplinary approach covering agrometeorology, statistics, mathematical modeling, and financial and risk management. This paper first offers an overview of data sources and then methods of design and valuation of weather derivatives at the regional level. The accompanied case study focuses on cultivation of cereals (wheat and barley) in the Czech Republic. However, its generalizability is straightforward. The analysis of key growing phases of cereals is based on regression analysis using weather indices as the independent variables and crop yields as dependent variables. With the bootstrap tool, the burn analysis is considered as useful tool for estimating uncertainty about the payoff, option price, and statistics of probability distribution of revenues. The results show that the spatial and production basis risks reduce the efficiency of the weather derivatives. Finally, the potential for expansion of weather derivatives remains in the low income countries of Africa and Asia with systemic weather risk.
\end{abstract}

\section{Introduction}

Weather determines decision making over the world $[1,2]$. Lazo et al. [3] quantify 3.4\% interannual aggregate dollar variation in US economic activity that is attributable to the weather variability. Nevertheless, the degree of the weather sensitivity in the high income countries is relatively small because of minor share of agriculture in GDP. On the contrary, the underdeveloped world and many emerging countries with the substantial share of agriculture in GDP and employment have to face the weather risks without sufficient financial resources and infrastructure to manage them.

A financial weather contract (weather derivative, weather index insurance) is a weather contingent contract whose payoff is determined by future weather events. The contract links payments to a weather index that is the collection of weather variables measured at a stated location during an explicit period [4]. Underlying "assets" of weather derivative are most often air temperature, rainfall, wind speed, and so forth. Many relevant studies test the potential use of the weather derivatives in agriculture [5-11].
The main advantage of the index-based financial tools is their power to reduce the information asymmetry [12-16]. The derivative payoff is estimated by objective, measurable, and transparent weather variable which cannot be intentionally modified by farmers or any other subject. Alternatively, the most important disadvantage of the weather derivatives and the index insurance they most frequently advert to is the basis risk. The cause of the production basis risk is that individual yield fluctuations in general are not perfectly correlated with the relevant weather variable. The spatial basis risk arises from the difference in weather patterns at the reference point of the derivative and the location of agricultural production [17].

There is also one important prerequisite for the efficient use of the weather derivatives in agriculture. The weather derivatives are more effective in hedging the revenue risk for products with a greater likelihood for low correlations between yield and price $[18,19]$. These arguments also raise the need to evaluate the price-yield concurrence.

This paper aims to assess the potential of the weather derivatives to reduce revenue risk in agriculture taking 
into consideration the growing conditions in the Czech Republic. The problem of risk management scheme in the Czech agriculture is that the systemic risks are not covered by insurance (drought, heat waves, and persistent rain at harvest).

The paper is organized as follows. The first part focuses on description of methodical approach for design and valuation of weather derivatives at the regional level. The second part presents results and discussion of the main findings, chances, and limitations of agricultural weather derivatives.

\section{Material and Methods}

Design and valuation of the weather derivatives is an interdisciplinary approach covering agrometeorology, statistics, mathematical modeling, and financial and risk management. The methodology is a modification of the procedures proposed by Jewson et al. [20], Mußhoff et al. [7], Hnilica [21], and Manfredo and Richards [22].

\section{Argometeorological Issues}

(1) Selection of regions suitable for construction of the weather derivatives.

(2) Selection of agricultural crops suitable for construction of the weather derivatives.

(3) Selection of relevant available data sources.

\section{Statistical Issues}

(4) Adjustment of data time series.

(5) Identification of underlying index of the weather derivatives.

\section{Mathematical Modeling}

(6) Identification of a suitable type of probability distribution of the index contract (weather). Risk layering.

(7) Weather derivative valuation.

\section{Risk Management Issues}

(8) Assessment of efficiency of the weather derivative contract to reduce revenue risk.

2.1. Agrometeorological Issues. Selection of regions for design of the weather derivatives is based on whether the agricultural production in the region is sufficiently important to ensure liquidity of the contract. Structural and economic data show that four Czech regions (Středočeský, Jihočeský, Vysočina, and Jihomoravský) produce more than 50\% of national agricultural output. In addition, the Olomoucký and Královéhradecký regions have relatively higher risk of drought because of large lowlands. These regions are also characterized by cereal production on fertile soils. Table 1 shows basic structural and economic characteristics of selected regions.

Barnett and Mahul [5] suggest at least 20 annual data on crop yields to set a contract price for the relatively frequent adverse weather events. In this paper, the 40-year time series (1970-2009) of crop yields are obtained from the Czech
Statistical Office (CSO). The CSO is a central governmental authority in processing and publishing official statistical information. The risk analysis requires the use of data on the sown areas instead of the harvest areas [19]. Because of lack of reliable data on the sown areas, the crop yield is calculated as the share of harvested production ( $t$ ) to the harvest area (ha).

Weather data are purchased from the Czech Hydrometeorological Institute (CHMI). The analysis uses the daily/ monthly average air temperatures and daily/monthly cumulative rainfall. Monthly weather data are the spatial averages of data provided by the professional meteorological stations located in selected six regions. We adopt the following weather indices-air temperature $\left({ }^{\circ} \mathrm{C}\right)$, rainfall $(\mathrm{mm})$, and drought index $S_{i}$ (combination of air temperature and rainfall, [23]) and CDD/HDD (i.e., the number of degrees that a day's average temperature is above/below a certain level). Basic air temperature of CDD is set using linear optimization to achieve the highest Pearson correlation coefficient between basic air temperature and crop yield.

2.2. Statistical Issues. The obvious technological progress in cultivation of the field crops requires detrending of the yield time series [9-11]. Linear, exponential, logarithmic, power, and polynomial (quadratic and cubic) trends are tested. The power trend is the most suitable for wheat and barley (according to the $R^{2}$ ). Deviations from trend are related to the 5-year average yield (2005-2009) when excluding the highest and lowest values in order to express the current average level of yields $\left(Y_{\mathrm{avg}}^{\mathrm{tr}}\right)$. The detrended data are then calculated as

$$
Y_{t}^{\text {detr }}=Y_{t} \frac{Y_{\mathrm{avg}}}{Y_{t}^{\mathrm{tr}}},
$$

where $Y_{t}$ denotes actual data in year $t$ and $Y_{t}^{\text {tr }}$ means the trend.

The regression analysis estimates the relationships between the weather index and the crop yields in critical period of vegetation (SPSS Statistics 18.0). Following types of regression functions are tested: linear, logarithmic, inverse, quadratic, cubic, power, $S$ curve, exponential, and logistic. In order to achieve the highest possible correlation between yield and weather variables, we set weights to the critical month of vegetation. The weights are set through the highest value of correlation coefficient between yield and weather variable during the critical period of vegetation (MS Excel Solver).

The simple linear regression between the crop yield and the weather index enables to clearly find the strike level (the level of index when the contract triggers). Then we set the tick (the payoff per one index point above/below the strike level) as an expected postharvest price and the regression coefficient $\beta$. The regression function is tested for autocorrelation (Breusch-Godfrey test) and heteroskedasticity (White test) at $\alpha=0.05$.

2.3. Mathematical Modeling. The analysis compares the effectiveness of the contracts for the two strike levels. The first strike covers risks with low frequency and high severity (strike 1). It assumes a certain degree of farmers' own contribution. At the strike 1 the probability of payoff ranges 
TABle 1: Basic characteristic of selected regions in the Czech Republic (2010).

\begin{tabular}{|c|c|c|c|c|c|c|}
\hline & Středočeský & Jihomoravský & Vysočina & Jihočeský & Královéhradecký & Olomoucký \\
\hline Agricultural holdings & 5,082 & 9,967 & 4,176 & 4,483 & 2,793 & 2,217 \\
\hline with agricultural land up to 10 ha & 2,748 & 8,615 & 2,505 & 2,554 & 1,727 & 1,313 \\
\hline $\begin{array}{l}\text { Agricultural output (CZK million, } \\
\text { current prices) }\end{array}$ & 18,939 & 12,341 & 11,408 & 11,216 & 7,637 & 7,099 \\
\hline Crop output & 12,162 & 7,670 & 5,337 & 5,028 & 4,056 & 4,008 \\
\hline Animal output & 6,180 & 3,997 & 5,653 & 5,419 & 3,304 & 2,389 \\
\hline Agricultural services output & 446 & 348 & 290 & 419 & 205 & 167 \\
\hline Utilised agricultural land (ha) & 663,524 & 362,381 & 364,600 & 422,246 & 234,041 & 244,172 \\
\hline Arable land & 551,096 & 321,537 & 283,052 & 258,465 & 168,653 & 177,223 \\
\hline Permanent grassland & 70,978 & 21,153 & 79,990 & 158,948 & 62,278 & 64,358 \\
\hline \multicolumn{7}{|l|}{ Crop production-harvest (tonnes) } \\
\hline Cereals, total & $1,388,775$ & $1,080,301$ & 610,140 & 624,183 & 426,944 & 520,048 \\
\hline Potatoes, total & 143,438 & 32,008 & 254,517 & 91,689 & 26,192 & 15,039 \\
\hline Rape & 210,270 & 95,015 & 112,472 & 120,983 & 62,776 & 64,283 \\
\hline \multicolumn{7}{|l|}{ Livestock production } \\
\hline \multicolumn{7}{|l|}{ Livestock intensity } \\
\hline Cattle (heads/100 ha agr. land) & 25.8 & 16.1 & 57.9 & 49.7 & 42.7 & 36.7 \\
\hline Pigs (heads/100 ha arable land) & 60.9 & 80.8 & 99.2 & 67.0 & 73.7 & 62.9 \\
\hline Meat production (tonnes) & 49,973 & 43,900 & 53,538 & 41,319 & 23,267 & 25,762 \\
\hline Milk production (thous. 1) & 324,039 & 146,827 & 447,592 & 319,395 & 205,659 & 178,612 \\
\hline
\end{tabular}

Source: Czech Statistical Office-Regional statistical yearbooks (http://www.czso.cz).

TABLE 2: The results of the test of various weather indices.

\begin{tabular}{|c|c|c|c|c|c|c|c|}
\hline & $T 2$ & T3 & $S_{i} 2$ & $S_{i} 3$ & CDD 1 & $\mathrm{CDD} 2$ & CDD 3 \\
\hline \multicolumn{8}{|l|}{ Wheat } \\
\hline \multirow{3}{*}{ Critical month (weight) } & & $4(0.074)$ & & $4(0.152)$ & & & \\
\hline & $5(0.257)$ & $5(0.213)$ & $5(0.555)$ & $5(0.440)$ & & & \\
\hline & $6(0.743)$ & $6(0.713)$ & $6(0.445)$ & $6(0.408)$ & & & \\
\hline \multirow{2}{*}{ Pearson correlation } & -0.69 & -0.693 & -0.617 & -0.632 & -0.503 & -0.522 & -0.569 \\
\hline & $(P<0.0001)$ & $(P<0.0001)$ & $(P<0.0001)$ & $(P<0.0001)$ & $(P=0.0009)$ & $(P=0.0005)$ & $(P=0.0001)$ \\
\hline$R^{2}$ & 0.477 & 0.481 & 0.381 & 0.399 & 0.253 & 0.273 & 0.323 \\
\hline \multicolumn{8}{|l|}{ Barley } \\
\hline \multirow{3}{*}{ Critical month (weight) } & & $4(0.194)$ & & $4(0.271)$ & & & \\
\hline & $5(0.264)$ & $5(0.149)$ & $5(0.500)$ & $5(0.307)$ & & & \\
\hline & $6(0.736)$ & $6(0.657)$ & $6(0.500)$ & $6(0.422)$ & & & \\
\hline \multirow{2}{*}{ Pearson correlation } & -0.666 & -0.688 & -0.592 & -0.645 & -0.459 & -0.45 & -0.497 \\
\hline & $(P<0.0001)$ & $(P<0.0001)$ & $(P<0.0001)$ & $(P<0.0001)$ & $(P=0.0029)$ & $(P=0.0036)$ & $(P=0.0011)$ \\
\hline$R^{2}$ & 0.443 & 0.473 & 0.35 & 0.416 & 0.211 & 0.2027 & 0.2472 \\
\hline
\end{tabular}

Source: authors.

from $10 \%$ to $15 \%$. The strike 2 represents relatively more frequent and less severe weather risks and requires no farmers' contribution.

Weather derivative pricing in the paper is based on the burn analysis. The burn analysis reflects how a contract has performed in previous years. Burn analysis in this paper is enhanced by distribution fitting and Monte Carlo simulation. The probability distribution of the weather index is estimated from the real data though the Maximum Likelihood Estimation (MLE) method [24]. The probability distribution is tested simultaneously through the Anderson-Darling test goodness-of-fit test (A-D) at $\alpha=0.05$.
Bootstrapping [25] allows for easier estimation of uncertainty surrounding the estimate of mean and standard deviation of payoff. The parametric bootstrap [24] requires the extra information about the probability distribution.

The contract price (in this case of an option) is the average expected contract payoff. Nevertheless, the seller of the option would probably expect a reward for taking on the risk of having to pay out, and, hence, the premium would probably be slightly higher than the expected payoff by a risk loading. In the paper, the risk loading as $20 \%$ of the standard deviation of the payoff of the contract is set [20]. 
2.4. Risk Management Issues. Efficiency of weather derivative to reduce risk is quantified by comparing the distribution of revenues from crop sales including hedging and without hedging (option 1, option 2). If the farmer does not buy a weather derivative contract, he would realize the revenues $R_{0}$ :

$$
R_{0}=\frac{Q \cdot P}{\left(1+r_{f}\right)^{n}}, \quad Q=\int_{\min }^{\max } f(x) d x
$$

$Q$ denotes crop yield ( $\mathrm{t} / \mathrm{ha}$ ) being a function of stochastic weather variable $x . P$ is expected postharvest crop price $(\mathrm{CZK} / \mathrm{t})$. Since the expected payoff $(Q \cdot P)$ is related to the beginning of the contract period, it is discounted by the riskfree rate $r_{f}$ at the beginning of the contract period $(1.90 \% \mathrm{p}$. a.).

If the farmer buys a weather derivative contract per 1 ha of crop, he has to pay the premium to the seller $\left(F_{0}\right)$. A farmer may collect a payoff from the contract $\left(F_{T}\right)$ if a weather variable exceeds the strike. The payment is a function of underlying index $x$. Consider

$$
R_{1}=R_{0}+\frac{F_{T}}{\left(1+r_{f}\right)^{n}}-F_{0}, \quad F_{T}=\int_{\min }^{\max } f(x) d x .
$$

The simulation is processed using the Monte Carlo method with 10000 iterations at $\alpha=0.05$. The comparison of the simulation results without standard error (without basis risk) and including standard error in regression estimate (including basis risk) answers the question about the degree of the basis risk.

\section{Results and Discussion}

Tables 6 and 7 present the results of correlation analysis between yields and weather variables. A statistically significant moderate relationship occurs between the wheat/barley yields and the air temperature (and drought index $S_{i}$ ) in May, June, and July. Both cereals have similar sensitivity to air temperature. Precipitations are local, so the risk of lack or, conversely, excessive rainfall has not a systematic character. The inverse relationship is shown between yield and rainfall during the presowing soil preparation. However, the correlations between wheat/barley yield and precipitation at the regional level are rather weak.

The results confirm the sensitivity of wheat/barley to the lack of precipitation and higher temperatures in the spring. On the contrary, rather drier periods in some regions are beneficial during pre-sowing soil preparation. Tables 6 and 7 show Jihomoravský region as the area with highest risk of drought, where the correlation coefficient between yields and drought index $S_{i}$ distinctly exceeded 0.5 and are statistically significant at $\alpha=0.01$. The higher risk means the higher yields - the Jihomoravský region is really a growing-friendly area for high quality wheat and barley.

Sensitivity of yields to weather variables in April is also worthy of attention, but not statistically significant. The following weather indices are included in the underlying index and tested for correlation:

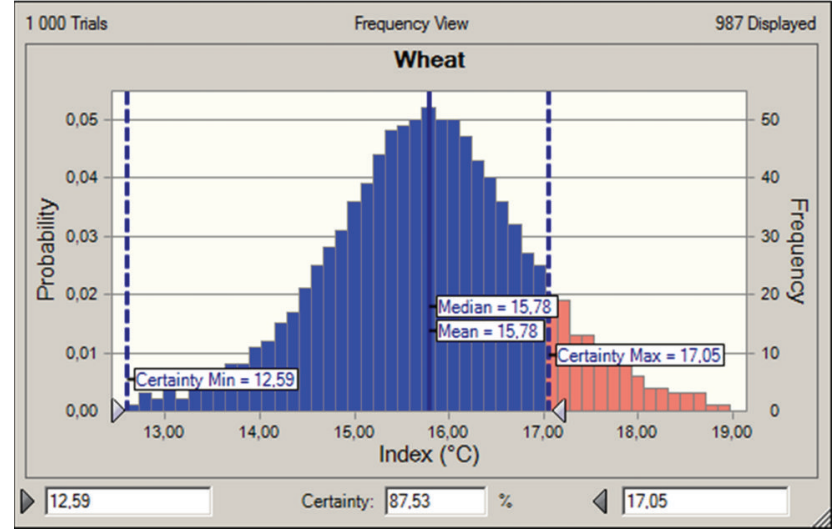

FIGURE 1: Risk layering with farmers' participation of $10 \%$ (strike 1) for wheat.

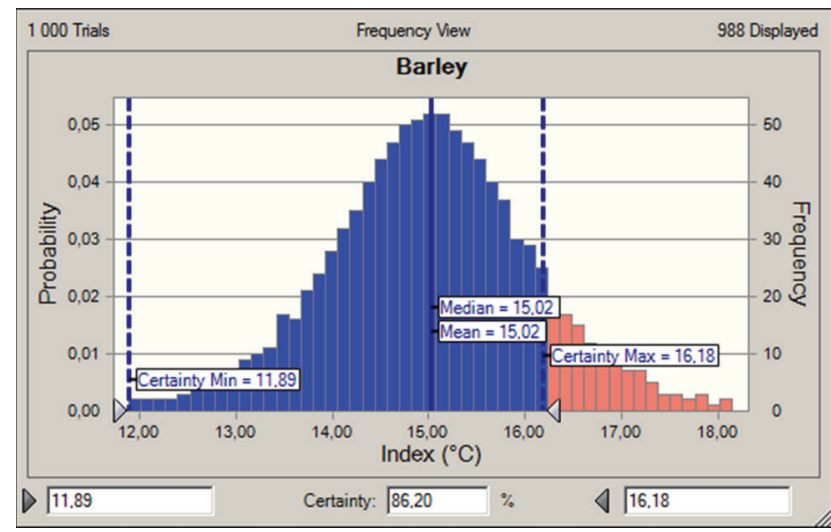

Figure 2: Risk layering with farmers' participation of $10 \%$ (strike 1) for barley.

(i) weighted average air temperature in the period MayJune (T2);

(ii) weighted average air temperature in the period from April to June (T3);

(iii) weighted drought index $S_{i}$ in the period from May to June $\left(S_{i} 2\right)$;

(iv) weighted drought index $S_{i}$ in the period April-June $\left(S_{i} 3\right)$;

(v) number of CDDs in June assuming basic air temperature $16.5^{\circ} \mathrm{C}$ (wheat) $/ 18.09^{\circ} \mathrm{C}$ (barley) (CDD 1);

(vi) number of CDDs in the period May-June assuming basic air temperature $13.9^{\circ} \mathrm{C}$ (wheat) $/ 15.0^{\circ} \mathrm{C}$ (barley) (CDD 2);

(vii) number of CDDs in the period April-June assuming basic air temperature $14.0^{\circ} \mathrm{C}$ for both wheat and barley (CDD 3).

The highest Pearson correlation coefficient is identified between wheat/barley yields and weighted average air temperature T3 (Table 2). Weather index therefore consists of an average air temperature in April (weight of $7.4 \%$ for wheat $/ 19.4 \%$ for barley), May (weight of $21.3 \%$ for 
TABLE 3: Results of the regression analysis.

\begin{tabular}{lcccccc}
\hline Crop/region & Regression & $R^{2}$ & Adj. $R^{2}$ & $\begin{array}{c}\text { Breusch-Godfrey } \\
\text { test }(P \text { value })\end{array}$ & $\begin{array}{c}\text { White test LM } \\
(P \text { value })\end{array}$ & $\begin{array}{c}\text { A-D test for } \\
\text { residuals } \\
(P \text { value })\end{array}$ \\
\hline Wheat/Jihomoravský & $y=-0.3987 x+11.2960$ & 0.481 & 0.467 & $\begin{array}{l}0.792216 \\
(0.379182)\end{array}$ & $\begin{array}{c}0.110964 \\
(0.946029)\end{array}$ \\
Barley/Jihomoravkḱ & $y=-0.3623 x+9.5613$ & 0.473 & 0.460 & $\begin{array}{l}0.778546 \\
(0.386845)\end{array}$ & $\begin{array}{l}0.593445 \\
(0.743250)\end{array}$ & 0.957 \\
\hline
\end{tabular}

Notes: Breusch-Godfrey test does not show the existence of autocorrelation in time series. White test did not indicate any presence of heteroskedasticity. Source: authors.

TABLE 4: Result of Anderson-Darling test of index T3 for wheat and barley.

\begin{tabular}{lccccc}
\hline \multirow{2}{*}{ Distribution } & \multicolumn{2}{c}{ Wheat } & \multirow{2}{*}{ Distribution } & \multicolumn{2}{c}{ Barley } \\
& A-D & $P$ value & & A-D & $P$ value \\
\hline Logistic & 0.3899 & 0.317 & Logistic & 0.2230 & 0.776 \\
Student's $t$ & 0.4792 & $\times$ & Lognormal & 0.2731 & 0.538 \\
Beta & 0.5144 & $\times$ & Beta & 0.2821 & $\times$ \\
Normal & 0.5146 & 0.193 & Gamma & 0.2867 & 0.55 \\
Lognormal & 0.5274 & 0.089 & Normal & 0.2889 & 0.623 \\
Gamma & 0.5383 & 0.099 & Weibull & 0.3096 & 0.524 \\
Weibull & 0.5941 & 0.223 & Max Extreme & 0.5899 & 0.128 \\
Max Extreme & 0.9252 & 0.018 & Student's $t$ & 1.0695 & $\times$ \\
Min Extreme & 1.6905 & 0 & Triangular & 1.2479 & $\times$ \\
Triangular & 2.4206 & $\times$ & Min Extreme & 1.3435 & 0 \\
Pareto & 5.4825 & $\times$ & Uniform & 4.1707 & 0 \\
Uniform & 5.5950 & 0 & Pareto & 4.7336 & $\times$ \\
BetaPERT & 12.5932 & $\times$ & BetaPERT & 6.8939 & $\times$ \\
Exponential & 19.5335 & 0 & Exponential & 19.4727 & 0 \\
\hline
\end{tabular}

Source: authors.

wheat/14.9\% for barley), and June (weight of $71.3 \%$ for wheat $/ 65.7 \%$ for barley).

Table 3 describes results of regression analysis between wheat/barley yields in Jihomoravský region and weather index T3.

The weather index explains the variability of regional average wheat/barley yields of up to $48.1 \% / 47.3 \%$. The remaining part of yield variability is caused by weather conditions during other months (e.g., weather during the harvest season, hail during the vegetation) and by other influences we can term as basis risk. According to the results of Anderson-Darling goodness-of-fit test, residuals are of the normal (Gaussian) distribution value of A-D test = 0.190 (wheat) $/ 0.152$ (barley) and $P$ value $=0.894$ (wheat) $/$ 0.957 (barley). Standard error is 0.500 (wheat) $/ 0.442$ (barley). These values are the essential inputs to quantify the effectiveness of the weather derivative with the basis risk assumption.

The type and parameters of the probability distribution are estimated using the Anderson-Darling goodness-of-fit test. A histogram of weighted average air temperature $T 3$ is based on historical weather data in the period of 19612009. Results of A-D test for both wheat and barley (Table 4) show that the most suitable approximation of real data probability distribution is logistic distribution with mean
TABLE 5: The structure of specific-event contracts and the efficiency assessment.

\begin{tabular}{lcc}
\hline & Wheat & Barley \\
\hline Region & $\begin{array}{c}\text { Jihomoravský } \\
\text { Air }\end{array}$ & Jihomoravský \\
Index & temperature & Air temperature \\
& April $(0.074)$ & April $(0.194)$ \\
Critical month for crop yield & May $(0.213)$ & May $(0.149)$ \\
formation (weights) & June $(0.713)$ & June $(0.657)$ \\
& $17.05^{\circ} \mathrm{C}$ & $16.18^{\circ} \mathrm{C}$ \\
Strike 1 & $15.80^{\circ} \mathrm{C}$ & $15.07^{\circ} \mathrm{C}$ \\
Strike 2 & Linear & Linear \\
Type of regression function & 0.481 & 0.473 \\
$R^{2}$ & $\mathrm{Call}$ & $\mathrm{Call}$ \\
Type of option & 4,600 & 3,700 \\
Fixed price $(\mathrm{CZK} / \mathrm{t})$ & $1,834 \mathrm{CZK} / 1^{\circ} \mathrm{C}$ & $1,341 \mathrm{CZK} / 1^{\circ} \mathrm{C}$ \\
Tick & &
\end{tabular}

Strike 1

Without basis risk

\begin{tabular}{lcc} 
Reduction of sales variability & $-11.7 \%$ & $-13.8 \%$ \\
Reduction of average sales & $-0.45 \%$ & $-0.47 \%$ \\
With basis risk & & \\
Reduction of sales variability & $-5.5 \%$ & $-5.7 \%$ \\
Reduction of average sales & $-0.41 \%$ & $-0.49 \%$ \\
contract price (CZK per 1 ha) & 240 & 190 \\
\hline
\end{tabular}

\section{Strike 2}

Without basis risk

$\begin{array}{lcc}\text { Reduction of sales variability } & -39.6 \% & -40.0 \% \\ \text { Reduction of average sales } & -1.10 \% & -0.88 \% \\ \text { With basis risk } & & \\ \text { Reduction of sales variability } & -16.0 \% & -14.3 \% \\ \text { Reduction of average sales } & -1.00 \% & -1.07 \% \\ \text { ontract price (CZK per } 1 \mathrm{ha}) & 1,000 & 690\end{array}$

Source: authors.

15.783 (wheat) $/ 15.018$ (barley) and scale 0.633 (wheat)/0.616 (barley). The logistic distribution of underlying index $T 3$ is therefore put in parametric bootstrapping.

Weather derivative valuation requires estimation of strike, that is, the level of index when the contract starts to pay. Figures 1 and 2 show the risk layering for wheat and barley with farmers' participation of $10 \%$. 
TABLE 6: The most significant correlation coefficients between wheat yield per hectare and the average characteristics of weather in regions of the CR (1970-2009).

\begin{tabular}{|c|c|c|c|}
\hline Region & Air temperature & Rainfall & Drought index $S_{i}$ \\
\hline \multirow{5}{*}{ Středočeský } & $-0.43(6, P=0.0059)$ & $0.35(4, P=0.0270)$ & $-0.33(4-5, P=0.0363)$ \\
\hline & $-0.42(5-6, P=0.0068)$ & $0.33(4-5, P=0.0373)$ & $0.43(10-12, t-1, P=0.0063)$ \\
\hline & $-0.35(5-7, P=0.0290)$ & $-0.38(10-12, t-1, P=0.0159)$ & $0.36(10, t-1, P=0.0263)$ \\
\hline & $-0.32(5-7, P=0.0422)$ & & $0.36(12, t-1, P=0.0242)$ \\
\hline & & & $0.35(10-11, t-1, P=0.0283)$ \\
\hline \multirow{3}{*}{ Jihočeský } & $-0.48(6, P=0.0016)$ & $0.40(2, P=0.0105)$ & $0.32(1, P=0.0473)$ \\
\hline & $-0.43(5-6, P=0.0060)$ & $-0.34(7, P=0.0301)$ & $0.32(10-12, t-1, P=0.0449)$ \\
\hline & $-0.34(5-7, P=0.0339)$ & $-0.32(10-12, t-1, P=0.0463)$ & \\
\hline \multirow{5}{*}{ Vysočina } & $-0.59(6, P<0.0001)$ & & $-0.42(6, P=0.0064)$ \\
\hline & $-0.53(5-6, P=0.0004)$ & & $-0.38(4-6, P=0.0153)$ \\
\hline & $-0.47(5-7, P=0.0024)$ & $x$ & $-0.36(5-6, P=0.0245)$ \\
\hline & $-0.45(4-6, P=0.0037)$ & & \\
\hline & $-0.43(6-7, P=0.0057)$ & & \\
\hline \multirow{3}{*}{ Královéhradecký } & $-0.41(6, P=0.0091)$ & $-0.43(6-8, P=0.0056)$ & \\
\hline & $-0.39(5-6, P=0.0122)$ & $-0.41(7-8, P=0.0090)$ & $x$ \\
\hline & & $-0.35(10-12, t-1, P=0.0295)$ & \\
\hline \multirow{5}{*}{ Jihomoravský } & $-0.66(6, P<0.0001)$ & $0.34(5, P=0.0304)$ & $-0.58(5-6, P<0.0001)$ \\
\hline & $-0.66(5-6, P<0.0001)$ & $0.33(4-6, P=0.0398)$ & $-0.56(4-6, P=0.0002)$ \\
\hline & $-0.60(4-6, P<0.0001)$ & $0.32(4-5, P=0.0418)$ & $-0.52(5, P=0.0005)$ \\
\hline & $-0.52(3-6, P=0.0005)$ & & $-0.48(3-6, P=0.0019)$ \\
\hline & $-0.50(5-7, P=0.0010)$ & & $-0.46(6, P=0.0027)$ \\
\hline \multirow{3}{*}{ Olomoucký } & $-0.45(6, P=0.0034)$ & & \\
\hline & $-0.42(5-6, P=0.0068)$ & $x$ & $\times$ \\
\hline & $-0.32(5-7, P=0.0418)$ & & \\
\hline
\end{tabular}

The data in front of round brackets are correlation coefficients. The figures in brackets denote critical months for yield formation. The $P$ values test the twotailed statistical significance of the correlation coefficient. The term " $x$ " indicates no statistically significant correlation (Pearson, Spearman) at significance level 0.05 . We put a maximum of 5 most statistically significant correlation coefficients.

Source: authors.

Under the assumption of the regression functions, expected crop yield, and farmers' participation $(0 \% / 10 \%)$, various levels of contract strike can be set as follows. For example, strike is $17.05^{\circ} \mathrm{C}$ (wheat) $/ 16.18^{\circ} \mathrm{C}$ (barley) if the farmers' participation is $10 \%$ and expected yield is $5.00 \mathrm{t} / \mathrm{ha}$ (wheat)/4.12 t/ha (barley). The probability of higher underlying index $T 3$ is $12.47 \%$ (wheat) $/ 13.80 \%$ (barley). In case of no farmers' participation and the same expected yields, the strike is lower- $15.80^{\circ} \mathrm{C}$ (wheat) $/ 15.07^{\circ} \mathrm{C}$ (barley). The probability of risk occurring is then about $50 \%$.

Simulation of average payoff and its standard deviation corresponds to the principle of actuarial pricing method as well as to the concept of fair price. Table 5 contains the assessment of the efficiency of the weather derivative contracts for wheat and barley in the Jihomoravský region.

The efficiency of weather derivative contract is relatively low-farmers can reduce the variability of revenues only by $5.5 \%$ (wheat) $/ 5.7 \%$ (barley) at the strike 1 and under assumption of the basis risk. The analysis reveals a very high basis risk which may result in both excessive and poor payoff. If we consider no basis risk and strike 1, the contract can help reduce the variability of revenues by $11.7 \%$ (wheat) $/ 13.8 \%$ (barley). However, the basis risk really exists. Strike 2 increases the likelihood of payoff, so the contract price and the reduction of average sales are obviously higher. Such reduction in sales could be for many farmers still acceptable if they want to manage systemic weather risk that is not insurable.

Limitation of powerful use of the weather derivatives in the Czech agriculture is both a geographical basis risk and production basis risk. Geographical basis risk can be reduced by locating the contract nearest to the reference weather station. Alternatively, the nature of such weather index contracts would increase the transaction costs (as the contract would not be standardized) and would eliminate the advantage of their transferability to the capital markets. Production basis risk cannot be influenced by the design of the weather derivative contract.

In the European conditions, the assessment of weather derivatives efficiency in agriculture was conducted in Germany in Brandenburg [7]. Brandenburg is relatively homogeneous region because it is located in large North German Lowland (Nordwestdeutsches Tiefland) with predominantly sandy soils and low water retention capacity. Weather derivative for wheat linked to total precipitation in April-June (measured at weather station Berlin-Tempelhof) refers to the regression function with $R^{2}=0.48$. Despite the relatively homogeneous conditions in the region, designed weather derivative was able to reduce the variability of wheat sales only by $11 \%$. The extent of basis risk and efficiency of weather derivative are close to results shown in the paper. 
TABLE 7: The most significant correlation coefficients between barley yield per hectare and the average characteristics of weather in regions of the CR (1970-2009).

\begin{tabular}{|c|c|c|c|}
\hline Region & Air temperature & Rainfall & Drought index $S_{i}$ \\
\hline \multirow{5}{*}{ Středočeský } & $-0.44(6, P=0.0047)$ & $0.31(4, P=0.0479)$ & $0.41(3, P=0.0085)$ \\
\hline & $-0.43(5-6, P=0.0056)$ & $-0.40(3, P=0.0115)$ & \\
\hline & $-0.41(5-7, P=0.0085)$ & $-0.33(12, t-1, P=0.0415)$ & \\
\hline & $-0.37(4-6, P=0.0174)$ & & \\
\hline & $-0.37(6-7, P=0.0185)$ & & \\
\hline \multirow{4}{*}{ Jihočeský } & $-0.50(6, P=0.0010)$ & \multirow{4}{*}{$x$} & $-0.31(6, P=0.0479)$ \\
\hline & $-0.39(6-7, P=0.0128)$ & & \\
\hline & $-0.39(5-6, P=0.0131)$ & & \\
\hline & $-0.36(5-7, P=0.0236)$ & & \\
\hline \multirow{5}{*}{ Vysočina } & $-0.52(6, P=0.0005)$ & $-0.35(3, P=0.0268)$ & $0.41(3, P=0.0086)$ \\
\hline & $-0.51(6-7, P=0.0007)$ & $-0.34(1-3, P=0.0337)$ & $-0.40(6, P=0.0010)$ \\
\hline & $-0.48(5-7, P=0.0015)$ & & $-0.38(4-6, P=0.0162)$ \\
\hline & $-0.46(4-7, P=0.0025)$ & & $-0.33(5-6, P=0.0382)$ \\
\hline & $-0.44(5-6, P=0.0043)$ & & \\
\hline \multirow{5}{*}{ Královéhradecký } & $-0.46(6, P=0.0028)$ & $-0.41(1-8, P=0.0081)$ & $0.42(3, P=0.0072)$ \\
\hline & $-0.43(5-6, P=0.0060)$ & $-0.41(1-7, P=0.0082)$ & $0.38(1-3, P=0.0157)$ \\
\hline & $-0.41(5-7, P=0.0089)$ & $-0.34(1-3, P=0.0302)$ & $0.36(2-3, P=0.0243)$ \\
\hline & $-0.38(6-7, P=0.0157)$ & $-0.34(3-8, P=0.0317)$ & $0.33(1-4, P=0.0379)$ \\
\hline & $-0.35(4-7, P=0.0250)$ & $-0.33(7-8, P=0.0391)$ & $-0.34(6, P=0.0345)$ \\
\hline \multirow{5}{*}{ Jihomoravský } & $-0.64(6, P<0.0001)$ & $0.36(4-6, P=0.0218)$ & $-0.60(4-6, P<0.0001)$ \\
\hline & $-0.64(5-6, P<0.0001)$ & $0.33(4-5, P=0.0387)$ & $-0.56(5-6, P=0.0002)$ \\
\hline & $-0.63(4-6, P<0.0001)$ & $-0.32(3, P=0.0439)$ & $-0.49(4-5, P=0.0012)$ \\
\hline & $-0.55(4-7, P=0.0002)$ & & $-0.47(6, P=0.0020)$ \\
\hline & $-0.54(5-7, P=0.0003)$ & & $-0.47(5, P=0.0021)$ \\
\hline \multirow{5}{*}{ Olomoucký } & $-0.46(6, P=0.0027)$ & $-0.41(3, P=0.0080)$ & $-0.36(6, P=0.0238)$ \\
\hline & $-0.46(5-6, P=0.0029)$ & $-0.36(1-3, P=0.0207)$ & $-0.34(5-6, P=0.0293)$ \\
\hline & $-0.40(5-7, P=0.0103)$ & $-0.32(1-4, P=0.0443)$ & $0.33(3, P=0.0376)$ \\
\hline & $-0.38(4-6, P=0.0171)$ & & \\
\hline & $-0.35(6-7, P=0.0279)$ & & \\
\hline
\end{tabular}

The data in front of round brackets are correlation coefficients. The figures in brackets denote critical months for yield formation. The $P$ values test the twotailed statistical significance of the correlation coefficient. The term " $x$ " indicates no statistically significant correlation (Pearson, Spearman) at significance level 0.05 . We put a maximum of 5 most statistically significant correlation coefficients.

Source: authors.

These results confirm the findings by Manfredo and Richards [22] and Vedenov and Barnett [10] emphasizing in particular the disadvantages of weather derivatives as primary crop insurance instruments. Nevertheless, the aggregation effect suggests that the potential for weather derivatives in agriculture can be greater than previously thought, particularly for aggregators of risk, such as reinsurers [11].

\section{Conclusion}

The paper aims to design the weather derivative under the specific conditions of agriculture. The analysis reveals some important findings.

(i) In the Czech agriculture, the weather index explains up to $48 \%$ of the variability of the average cereal yields. More than $50 \%$ of the systemic yield risk cannot be covered by weather derivatives or weather insurance.

(ii) The main limitations on the use of the weather derivatives in the Czech Republic are heterogeneous production conditions that reduce the correlation between weather and crop yields at regional level. The Pearson correlation coefficients do not exceed \pm 0.7 and show weak or moderate correlation between regional yield and weather.

(iii) The analysis indicates high basis risk that can significantly distort the contract payoff. In the Czech Republic, the weather index contracts can reduce variability of the cereal revenues only by 5\%-6\%. If the basis risk does not exist, the contract is able to reduce variability of the cereal revenues by more than $10 \%$.

(iv) The efficiency of weather contracts increases with higher probability of damage. At the higher strike level, the designed contract reduces the sales variability by $14 \%-16 \%$ (basis risk) or $40 \%$ (no basis risk). However, the contract price is higher.

(v) The higher contract price reduces revenues from $-0.4 \%$ to $-1.0 \%$ (basis risk). Nevertheless, this is lower than the 3\% normative insurance premium rate against natural disasters. From the farmers' point 
of view it could be budget-wise to use weather derivatives with little efficiency but at low cost.

(vi) Assuming the potential of weather derivatives as the reinsurance instrument, it is important to clarify the legal and institutional aspects of the income risk management in agriculture using weather derivatives, especially regulation and possible areas of cooperation between the public and private sectors.

\section{Acknowledgment}

The research was supported by the long-term institutional support to the conceptual development of research organization (project of the University of Economics, Faculty of Business Administration, IGA 2, VŠE IP300040).

\section{References}

[1] J. A. Dutton, "Opportunities and priorities in a new era for weather and climate services," Bulletin of the American Meteorological Society, vol. 83, no. 9, pp. 1303-1311, 2002.

[2] M. Roth, Ch. Ulardic, and J. Trueb, "Critical success factors for weather risk transfer solutions in the agricultural sector: a reinsurer's view," Agricultural Finance Review, vol. 68, no. 1, pp. $1-7,2008$.

[3] J. K. Lazo, M. Lawson, P. H. Larsen, and D. M. Waldman, "U.S. economic sensitivity to weather variability," Bulletin of the American Meteorological Society, vol. 92, no. 6, pp. 709-720, 2011.

[4] R. S. Dishel, "Introduction to the weather market: dawn to midmorning climate risk and weather market," in Financial Risk Management With Weather Hedges, R. S. Dishel, Ed., pp. 3-24, Risk Books, London, UK, 2002.

[5] B. J. Barnett and O. Mahul, "Weather index insurance for agriculture and rural areas in lower-income countries," American Journal of Agricultural Economics, vol. 89, no. 5, pp. 1241-1247, 2007.

[6] M. Miranda and D. V. Vedenov, "Innovations in agricultural and natural disaster insurance," American Journal of Agricultural Economics, vol. 83, no. 3, pp. 650-655, 2001.

[7] O. Mußhoff, M. Odening, and W. Xu, "Zur Quantifizierung des Basisrisikos von Wetterderivaten,” Tech. Rep. 14947, German Association of Agricultural Economists, Giessen, Germany, 2006.

[8] J. R. Skees, "Innovations in index insurance for the poor in lower income countries," Agricultural and Resource Economics Review, vol. 37, no. 1, pp. 1-15, 2008.

[9] C. G. Turvey, "Weather derivatives for specific events risk in agriculture," Review of Agricultural Economics, vol. 23, no. 2, pp. 333-351, 2001.

[10] D. V. Vedenov and B. J. Barnett, "Efficiency of weather derivatives as primary crop insurance instruments," Journal of Agricultural and Resource Economics, vol. 29, no. 3, pp. 387-403, 2004.

[11] J. D. Woodard and P. Garcia, "Weather derivatives, spatial aggregation, and systemic risk: implications for reinsurance hedging," Journal of Agricultural and Resource Economics, vol. 33, no. 1, pp. 34-51, 2008.
[12] J. B. Hardaker, R. B. M. Huirne, J. R. Anderson, and G. Lien, Coping with Risk in Agriculture, CABI, Wallingford, UK, 2nd edition, 2004.

[13] J. K. Horowitz and E. Lichtenberg, "Insurance, moral hazard, and chemical use in agriculture," American Journal of Agricultural Economics, vol. 75, no. 4, pp. 926-935, 1993.

[14] S. S. Makki and A. Somwaru, "Evidence of adverse selection in crop insurance markets," The Journal of Risk and Insurance, vol. 68, no. 4, pp. 685-708, 2001.

[15] M. Rothschild and J. E. Stiglitz, "Equilibrium in competitive insurance markets: an essay on the economics of imperfect information," Quarterly Journal of Economics, vol. 90, no. 4, pp. 629-649, 1976

[16] A. Rubinstein and M. E. Yaari, "Repeated insurance contracts and moral hazard," Journal of Economic Theory, vol. 30, no. 1, pp. 74-97, 1983.

[17] U. Hess, "Weather index insurance for coping with risks in agricultural production," in Managing Weather and Climate Risks in Agriculture, M. V. K. Sivakumar and R. P. Motha, Eds., Springer, Berlin, Germany, 2007.

[18] T. A. Fleege, T. J. Richards, M. R. Manfredo, and D. R. Sanders, "The performance of weather derivatives in managing risks of specialty crops," in Proceedings of the NCR-134 Conference on Applied Commodity Price Analysis, Forecasting, and Market Risk Management, St. Louis, Mo, USA, April 2004.

[19] M. P. M. Meuwissen, M. A. P. M. van Asseldonk, and R. B. M. Huirne, "The feasibility of a derivative for the potato processing industry in Netherlands," in Proceedings of the Meeting of the Southern Association of Economics and Risk Management in Agriculture, Gulf Shores, Ala, USA, March 2000.

[20] S. Jewson, A. Brix, and C. Ziehmann, Weather Derivative Valuation: the Meteorological, Statistical, Financial and Mathematical Foundations, Cambridge University Press, Cambridge, UK, 2005.

[21] J. Hnilica, "Crystal ball in weather-linked derivatives valuation," in Proceedings of the Crystal Ball User Conference, Denver, Colo, USA, May 2007.

[22] M. R. Manfredo and T. J. Richards, "Hedging with weather derivatives: a role for options in reducing basis risk," Applied Financial Economics, vol. 19, no. 2, pp. 87-97, 2009.

[23] V. Potop, L. Türkott, and V. Kožnarová, "Spatiotemporal characteristics of drought episodes in czechia," Scientia Agriculturae Bohemica, vol. 39, no. 3, pp. 258-268, 2008.

[24] D. Vose, Risk Analysis: A Quantitative Guide, John Wiley \& Sons, Chichester, UK, 3rd edition, 2008.

[25] B. Efron, "Bootstrap methods: another look at the jackknife," Annals of Statistics, vol. 7, no. 1, pp. 1-26, 1979. 

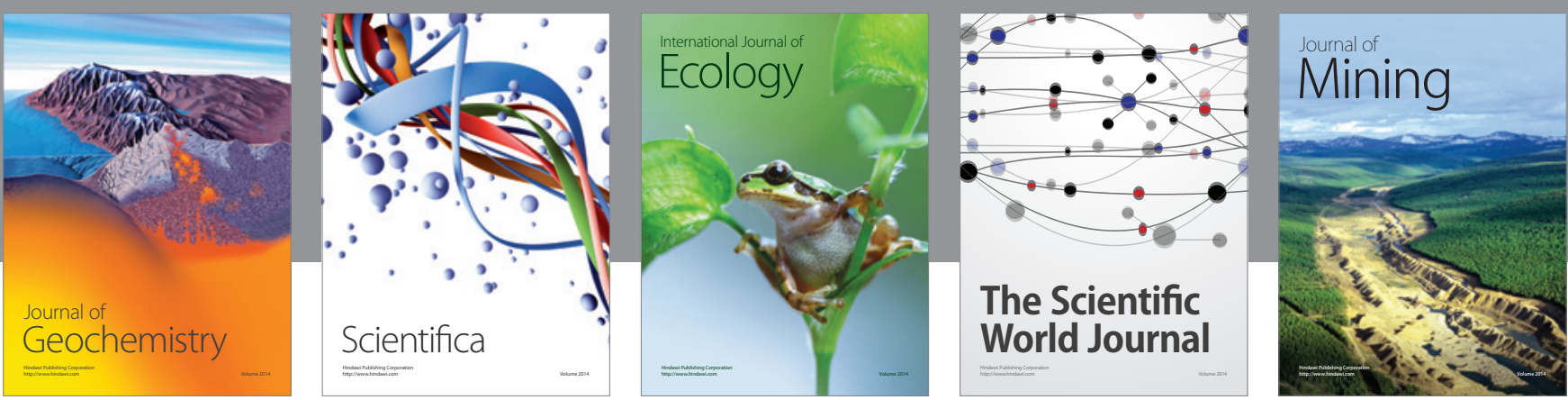

The Scientific World Journal
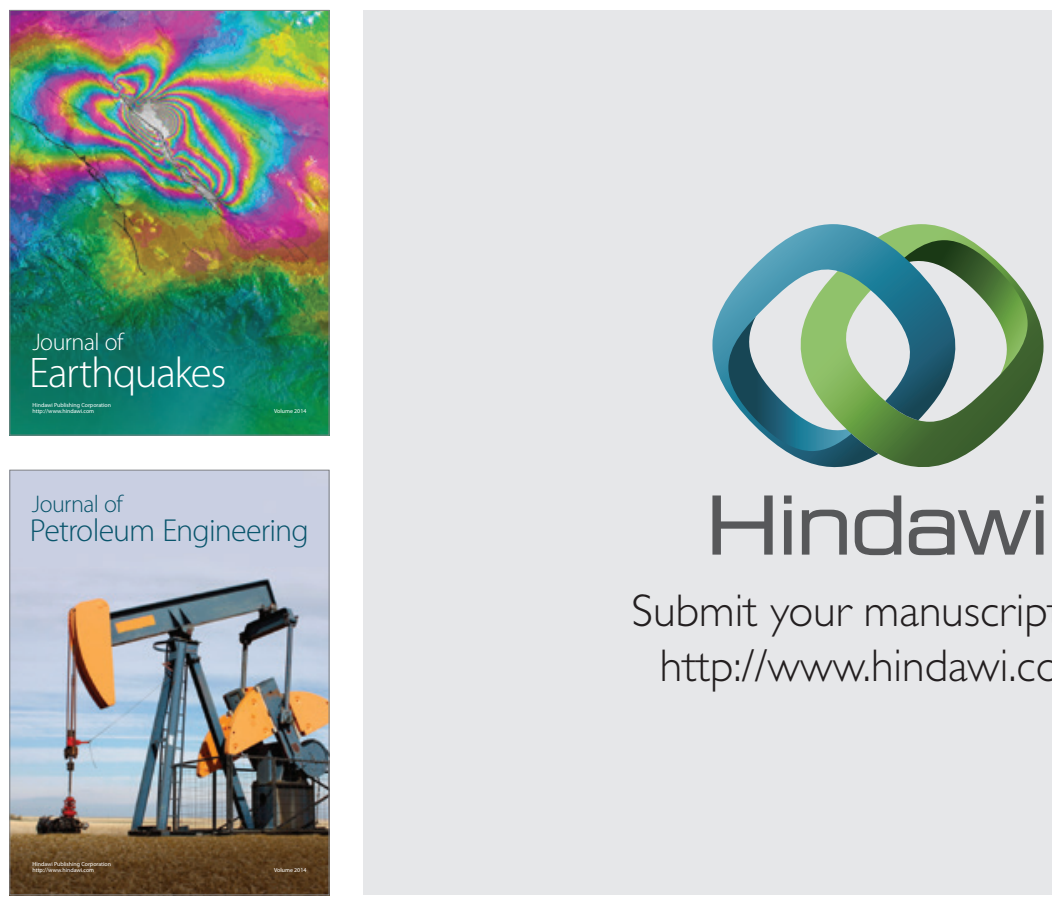

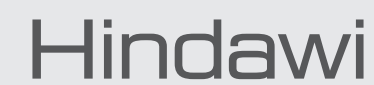

Submit your manuscripts at

http://www.hindawi.com
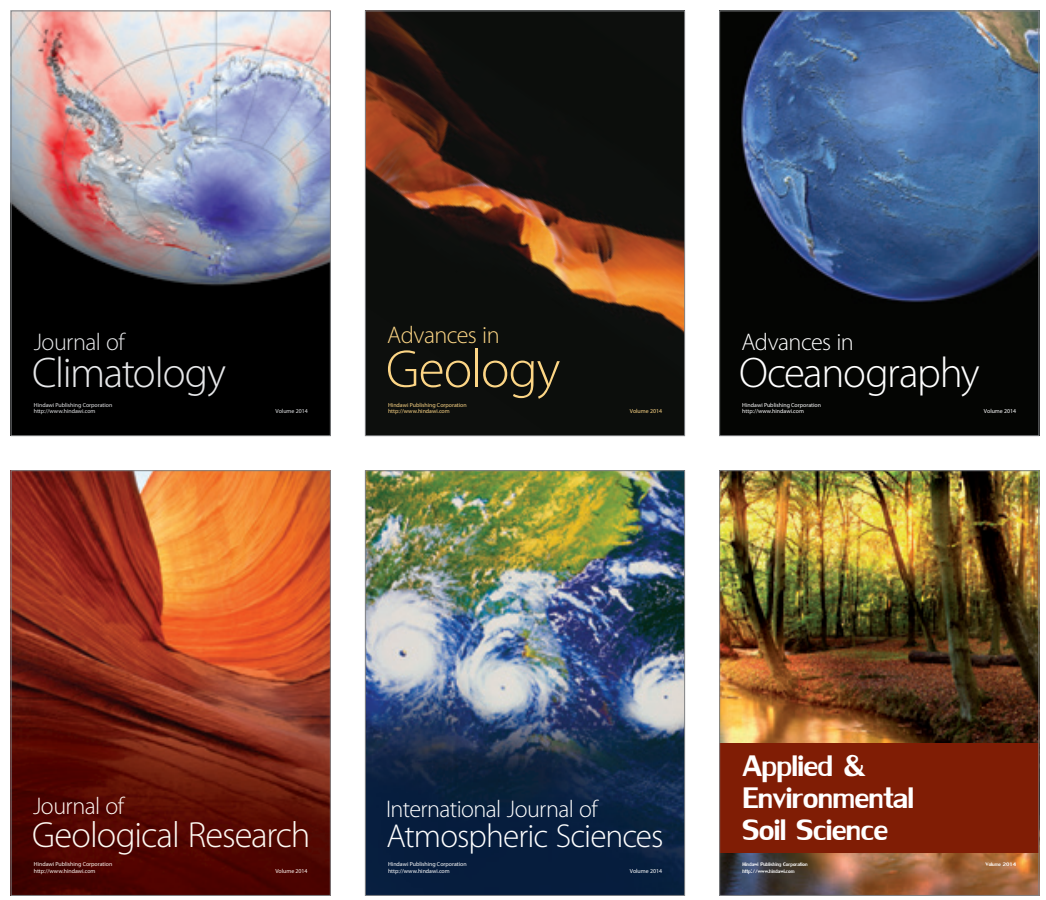
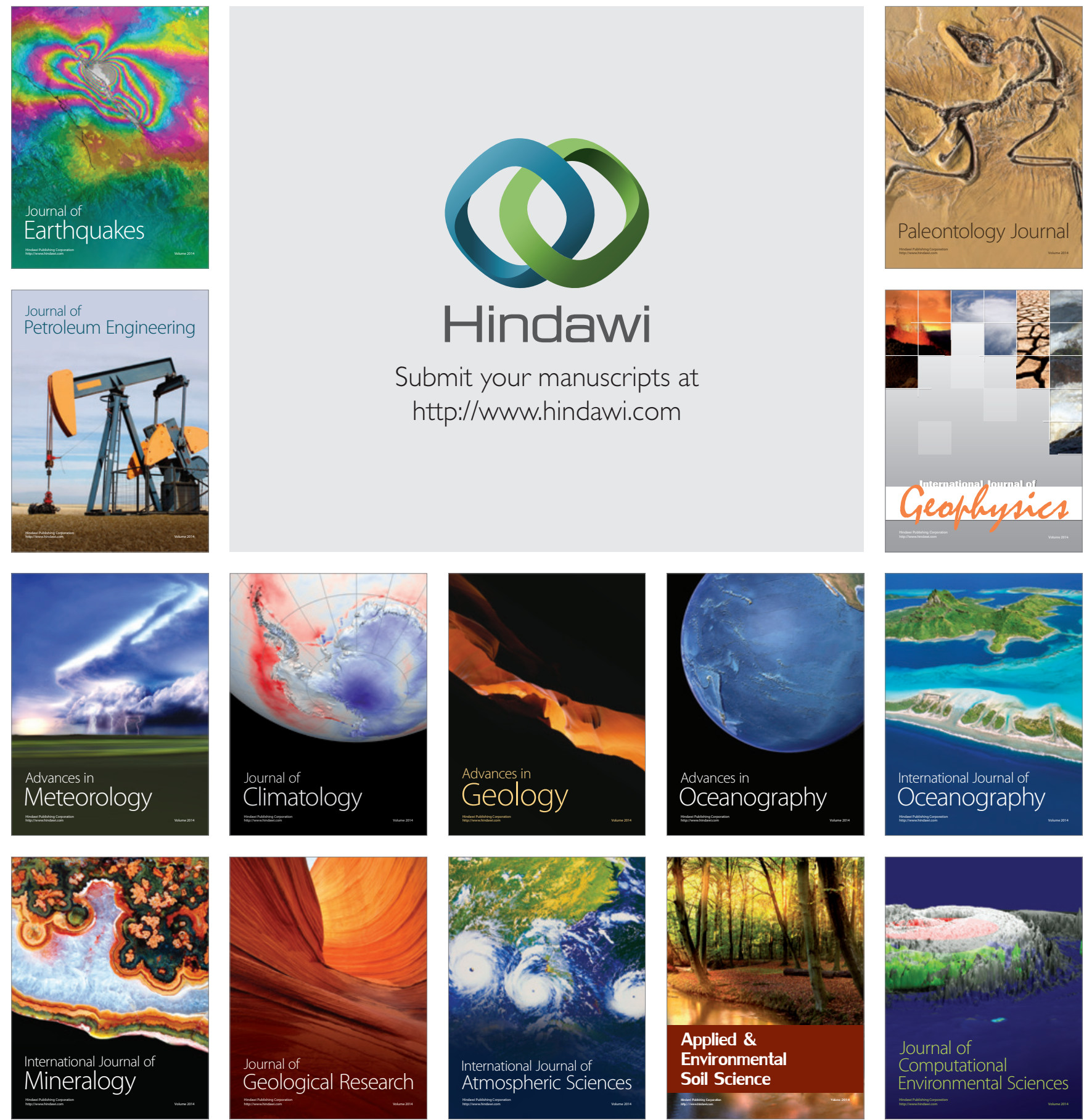